\title{
STATE AND RELIGION IN ATHENIAN INSCRIPTIONS
}

\author{
By P. J. RHODES
}

In our present-day secular society, which regards religion as an optional extra for those who like that sort of thing, it is trumpeted as a great discovery that, in classical Greece, religion was not an optional extra detached from the rest of society's working but was 'embedded' in the various workings of society. ${ }^{1}$ It is of course our society that is exceptional: religion has been embedded in most societies through most of human history. Christianity was far more effectively embedded in western societies in the past than it is now; there are still some links in England between the Church of England and the state, and there are rather stronger links in Norway between the Lutheran church and the state; some Christian festivals are still widely observed as public holidays; and, in other parts of the world (for instance, many countries in which Islam is the predominant religion), the links between religion and state are still much stronger.

In Athens, and in the Greek world generally, the notion of a separation between church and state was unthinkable. What I want to do here is to look at Athenian inscriptions, particularly decrees of the council and assembly, to see the range of state involvement in religion that is attested in them.

The first thing to note is that, while we have few inscribed Athenian decrees earlier than the 450 s, the majority of those that we do have are concerned with religious matters. ${ }^{2}$ In connection with Eleusis, we have a decree of the assembly, of c.500, that regulates sacrifices and shows that, at that time, the Eleusinian hieropoioi (best described as cult administrators, in contrast to the priests who actually peformed

\footnotetext{
* This article is revised from the paper which I read to the meeting of the British Epigraphy Society in Durham on 3 May 2008. My thanks to Dr P. Ceccarelli and Dr T. Kaizer, for organizing the meeting and inviting me to speak at it; and to all who heard the paper and discussed it with me, expecially Dr S. D. Lambert and Prof. R. C. T. Parker.

1 'Embedded' was first used in connection with religion by R. Parker in J. Boardman, J. Griffin, and O. Murray (eds.), The Oxford History of the Classical World (Oxford, 1986), 265-6; E. Kearns, in the article on 'religion, Greek' in $O C D^{3}$, makes the point without using the word (1300).

${ }^{2}$ Only $I G \mathrm{i}^{3}$ 1, on Salamis, and perhaps 2, whose subject is uncertain (3, cited below, is inscribed on the back of it), are not religious.
} 
religious rituals) were appointed by and/or from the deme of Eleusis. ${ }^{3}$ There is also a long text of $c .460$ concerned with the truce for the Mysteries, and with financial matters including the offerings to be made by candidates for initiation: it lacks a prescript but, since it specifies that the hieropoioi are to keep their treasury on the Acropolis and that, as with the treasury of Athena, the demos may use these funds as it wishes, we may assume that it was issued by the council and assembly rather than by Eleusinian officials. ${ }^{4}$ From the period c.500 we have fragments of sacred regulations from the city Eleusinium, apparently a consolidated re-edition of earlier texts, but we do not know on whose authority these were published. ${ }^{5}$

Otherwise, dated to the 480 s we have a decree providing for the appointment of athlothetai to supervise games at Marathon in honour of Heracles; ${ }^{6}$ and, with the archon of 485/484 restored, decrees about the Acropolis which involve penalties, treasurers, priestesses and zakoroi, and a single prytanis (whom I believe not to be one of a tribal contingent in the council of 500), and which are particularly concerned with the hekatompedon and its contents. ${ }^{7}$ Assigned to the 450s are a decree which responds to the Praxiergidae - a genos concerned with the cult of Athena Polias and particularly with the clothing of her statue - by authorizing the inscription at Athena's expense of an oracle and a list of their patria ${ }^{8}$ and also a decree about payments by sailors towards the cult of Poseidon at Sunium. ${ }^{9}$

Since there was no ecumenical council combining the functionaries of different cults, we may assume that a calendar of festivals of various gods, such as one dated c.480-460, was published on the authority not of a religious body but of the demos or a subdivision of the demos. ${ }^{10} \mathrm{~A}$ fragmentary text dated c.480-450 perhaps included a decree of the council, a thesmos concerning the deme of Melite and a

${ }^{3} I G \mathrm{i}^{3} 5=\mathrm{K}$. Clinton, Eleusis. The Inscriptions on Stone (Athens, 2005) (henceforth Clinton), no. 13. See M. B. Cavanaugh, Eleusis and Athens. Documents in Finance, Religion and Politics in the Fifth Century B.C. (Atlanta, 1996) (henceforth Cavanaugh), 74. For the second half of the fourth century, Ath. Pol. 54.6-7 mentions two boards of hieropoioi appointed by lot from the citizen body, one of them responsible for major festivals, including the quadrennial Eleusinia.

${ }^{4} I G \mathrm{i}^{3} 6=$ Clinton, no. 19 (dating it c.470-460), esp. C. 32-8. See Cavanaugh, 73-4.

${ }^{5} I G \mathrm{i}^{3} 231=$ Clinton, no. 7 (dating it c.510-500), 232. See L. H. Jeffery, 'Boustrophedon Inscriptions from the Agora', Hesp. 17 (1948), 86-111; idem, The Local Scripts of Archaic Greece (Oxford, 1961), 75-6.

${ }^{6} I G \mathrm{i}^{3} 3$.

$7 I G \mathrm{i}^{3} 4$.

${ }^{8} I G \mathrm{i}^{3}$ 7. On the Praxiergidae, see R. Parker, Athenian Religion. A History (Oxford, 1996), $307-8$.

$9 I G \mathrm{i}^{3} 8$.

${ }^{10} I G \mathrm{i}^{3} 234$. 
decree of that deme; ${ }^{11}$ better preserved is a text of the same period concerning the deme Scambonidae, which combines regulations for sacrifices and an oath to be sworn by officials of the deme; ${ }^{12}$ and, from slightly later, we have a list of sacrifices from the deme of Paeania, ${ }^{13}$ and, from Icaria, accounts and a decree concerned particularly with the rural Dionysia. ${ }^{14}$ There is also a calendar from Thoricus, which was dated c.385-370 when first published but more probably belongs to the second half of the fifth century. ${ }^{15}$

From the 450s onwards, decrees concerning other subjects become much more frequent, but those on religious subjects continue. For the Eleusinian cult, we have two major decrees. What is better regarded as the earlier, and dated not later than $c .435$ (because it contains no sign of the epistatai instituted by the other decree), was enacted (like a few other fifth-century decrees) on the proposal of an ad hoc board of syngrapheis, and is concerned with the offering of first-fruits of barley and wheat at Eleusis, 'in accordance with tradition and the oracle from Delphi'. ${ }^{16}$ It specifies the proportions of the harvest to be offered and the arrangements for collecting the offerings - from the Athenians, by their demarchs; from the allies (that is, the member states of the Delian League), by officials appointed in each city - and, although here it cannot command, it invites the other Greek states to make offerings too ( $\mu \dot{\epsilon} \epsilon \dot{\epsilon} \pi \tau \alpha \dot{\tau} \tau o \nu \tau \alpha S, \kappa \epsilon \lambda \epsilon \dot{v} o \nu \tau \alpha S \delta \dot{\epsilon}$ ). It prescribes arrangements for building granaries, performing sacrifices, and selling the remaining offerings and making dedications from the proceeds. Most of the work is to be done by the hieropoioi; 'the architect' is to be involved with the granaries; cult officials, the hierophant and daidouchos, are formally to call for offerings; and the sacrifices are to be performed in acordance with the exegesis of the Eumolpidae. But the council is responsible for sending heralds to convey the demand for offerings to the allies, and the council and assembly are to be involved in deciding on the dedications to be made. A first amendment, departing from the subject of the main decree, calls for the intercalation of a second month, Hecatombaeon, in the current year,

$11 I G \mathrm{i}^{3} 243$.

$12 I G \mathrm{i}^{3} 244$.

$13 I G \mathrm{i}^{3} 250$.

$14 I G \mathrm{i}^{3} 253,254$.

$15 S E G$ xxxiii 147; for a date in the 430 s or 420 s, see $I G \mathrm{i}^{3} 256$ bis (p. 958), with reference to discussions by D. M. Lewis and H. B. Mattingly.

${ }^{16} \mathrm{M} \& \mathrm{~L} 73=I G \mathrm{i}^{3} 78=$ Clinton, no. 28, trans. Fornara 140 (Clinton dates it c.440-435). See Cavanaugh, 73-95. 
and for the basileus to be involved in protecting the sacred area around the Acropolis known as the Pelargikon. In a second amendment, Lampon gets himself commissioned to draw up proposals (syngraphein) concerning the first-fruits of olive oil and requires the council to put his proposals to the assembly.

In the other text, the original decree is almost entirely lost, but there is a substantial amendment which provides for the annual appointment of five epistatai, who are to be responsible for the treasury of the goddesses, apply to the council if they need to collect sums due to the treasury, and make payments in consultation with the priests and the council; their expenditure is to be vetted by 'the logistai'. A reference in the imperfect tense to the epistatai of the Parthenon and the chryselephantine Athena suggests that this should be dated 432 or later, after Pericles' Acropolis building programme had been wound up. ${ }^{17}$

Concerned with Eleusis in a different way is a decree of 422/421, ordering the building of a bridge over one of the two streams called Rheitoi, for the safe conveyance of the sacred objects and the priestesses in the procession for the Mysteries: it was to be a pedestrian bridge, too narrow for vehicles, built of stone reused from 'the old temple', and the architect was specified. ${ }^{18}$

It was not only to Eleusis that the allies were required to send offerings. Erythrae, an Ionian city in the strict sense, was ordered at the end of the 450s to send offerings of grain for the Great Panathenaea; ${ }^{19}$ the colony founded at Brea in the 440 s or 430 s had to send a cow and panoply for the Great Panathenaea and a phallus for the Dionysia; ${ }^{20}$ and in the 420 s all the allies were ordered to send a cow and panoply. ${ }^{21}$

Before the middle of the fifth century, some religious buildings were paid for, and presumably erected through the agency of, private individuals: for instance, Themistocles was responsible for rebuilding the telesterion in Phlya and for building a sanctuary of Artemis Aristoboule in Melite, ${ }^{22}$ and Cimon was responsible for various public

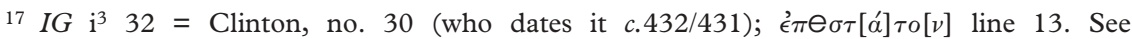
Cavanaugh, 19-27, 73-95. I think the dates given for these two inscriptions can withstand the review of Cavanaugh by V. J. Rosivach, BMCR 97.2.22.

$18 I G \mathrm{ii}^{3} 79=$ Clinton, no. 41 .

$19 \mathrm{M} \& \mathrm{~L} 40=I G \mathrm{i}^{3} 14$, trans. Fornara 71 (two reconstructions), 4-7.

20 M\&L $49=I G \mathrm{i}^{3} 46$, trans. Fornara 100, 15-17.

$21 \mathrm{M} \& \mathrm{~L} 69=I G \mathrm{i}^{3} 71$, trans. Fornara 136, 55-8; M\&L $46=I G \mathrm{i}^{3} 34$, trans. Fornara 98, 41-3 (I now date $46=34$ shortly after $69=71$ ).

22 Plut. Them. 1.4, 22.2-3. 
works. ${ }^{23}$ But what about the temple of Athena begun in the 480 s, and the Athenian stoa at Delphi, the latter dedicated by Athenaioi and probably funded from the sale of booty? ${ }^{24} \mathrm{R}$. T. Neer has argued that both of these, which in their iconography echoed the Alcmaeonids' temple of Apollo at Delphi, were emphatically works of the Athenian people, by implication claiming the Alcmaeonids' temple for the Athenian people too. ${ }^{25}$ But how was all this work and the payment for it organized? I wish we knew.

For the major buildings on the Acropolis in the second half of the century, we do not have the decrees ordering their construction, but we do have a decree - one of the two financial decrees which I still think are best dated 434/433 - which brings the Periclean programme to an end; ${ }^{26}$ and we know from their published records that each project was supervised by a board of publicly appointed epistatai. ${ }^{27}$ Notoriously, Pericles' enemies accused him of spending on buildings Delian League tribute which ought to have been used on fighting against the Persians: ${ }^{28}$ the scheme devised by the authors of The Athenian Tribute Lists, based on the assumption that the first of those financial decrees records the completion of a series of annual transfers from the League treasury to the treasury of Athena, was wildly

23 A list of his building works is in W. Judeich, Topographie von Athen, H.d.A. III. iii. 2, second edition (Munich, 1931), 73-4. J. K. Davies, Athenian Propertied Families, 600-300 B.C. (Oxford, 1971), 311, remarks, 'It is impossible ... to distinguish clearly which of them were paid for out of Kimon's private fortune rather than booty'.

24 M\&L 25, trans. Fornara 43.

25 R. T. Neer, 'Delphi, Olympia and the Art of Politics', in H. A. Shapiro (ed.), The Cambridge Companion to Archaic Greece (Cambridge, 2007), 247-51.

${ }^{26} \mathrm{M} \& \mathrm{~L} 58=I G \mathrm{i}^{3}$ 52, trans. Fornara 119: building programme $B$. 3-17. According to C. W. Fornara, a squeeze in Berlin shows that the proposer of the second decree was not Callias, the proposer of the first: in A. L. Pierris (ed.), Mind, Might, Money: The Secular Triad in Golden Age Athens (Proceedings of the Symposium Laureoticum, Sunium, 16-24 July 2006), Institute for Philosophical Research, Conference Series 8 (Patras, forthcoming).

The dating of the two decrees to the same day was fragile, but I still think that the two decrees could belong to the same year. For 434/433: the first decree ordered the creation of the treasury of the Other Gods and is therefore earlier than their earliest attested existence, in 430/429 (in IG $\mathrm{i}^{3} 383$, the treasurers of $429 / 428$ record what they took over from their predecessors); and the second decree is later than the beginning of the Propylaea in 437/436 and belongs to a year of the Great Panathenaea (Propylaea mentioned B. 3, 9; in B. 27-8, 'from Panathenaea to Panathenaea' defines the year being used, as in $A$. 27-8, but references to 'the four archai' must be to quadrennia based on the Great Panathenaea, as in other financial inscriptions such as $I G \mathrm{i}^{3}$ 292. 1, 369. 1: cf. P. J. Rhodes, The Athenian Boule [Oxford, 1972], 235-6). The inscribed records of the treasurers of Athena are based on Panathenaic quadrennia and begin in 434/433 $\left(I G \mathrm{i}^{3} 292,317,343\right)$, and that is still the most likely year for the two decrees and for the creation of the treasury of the Other Gods.

27 IG i i $^{3} 36-66$.
Cf. Plut. Per. $12-14$. 
speculative and has been undermined by L. Kallet-Marx, ${ }^{29}$ but it is still possible that some transfers were made somehow. Otherwise, on the funding of the buildings, we should set aside as too uncertain Demosthenes' 'from the barbarians' and the comment on that in the Anonymus Argentinensis; ${ }^{30}$ but we have the statement of Thucydides that the major fund on the Acropolis - which I take to be the treasury of Athena - paid for the Propylaea and 'the other buildings', while the accounts of the epistatai include receipts from the treasurers of Athena, and the one-sixtieth of the tribute which was given to Athena in any case, straight from the hellenotamiai. ${ }^{31}$

We do have two decrees for Athena Nike. The first orders the gating of the sanctuary and the building of a temple and altar (specifying the architect), and the appointment of a priestess by lot from all Athenian women - one of the few features of religion in democratic Athens which can be seen as distinctively democratic - to receive a stipend and a share of the sacrifice; an amendment provides for three members of the council to join the architect in drawing up a schedule for the contract. The second, in 424/423 - and here I do not need to date the first - orders the payment of the priestess's stipend. ${ }^{32}$ There is also a fragmentary text which shows the further involvement of the council and people in the arrangements for building the temple. ${ }^{33}$

To return to finance: the treasurers of Athena had long existed, and they were state officials at least from the time of Solon, under whose laws they were appointed by lot from the highest census class, the pentakosiomedimnoi. ${ }^{34}$ The financial decrees of $434 / 433$ created an amalgamated board of treasurers of the Other Gods, to share

29 See B. D. Meritt, H. T. Wade-Gery, and M. F. McGregor, The Athenian Tribute Lists, iii (Princeton, 1950), 281, 326-9; L. Kallet-Marx, 'Did Tribute Fund the Parthenon?', Cl. Ant. 8 = CSCA 20 (1989), 252-66.

30 Dem. 22. Androtion 13; for P. Strasb. 84, C. W. Fornara, Translated Documents of Greece and Rome, i. Archaic Times to the End of the Peloponnesian War, second edition (Cambridge, 1983), no. 94, gives references to and translations of three different reconstructions.

31 Thuc. 2.13.3; for the accounts, see e.g. $I G \mathrm{i}^{3}$ 439. 69-74 (Parthenon), M\&L 60. 9-13= $I G \mathrm{i}^{3} 465$, trans. Fornara 118, B. 121-5 (Propylaea).

32 M\&L 44, $71=I G \mathrm{i}^{3}$ 35, 36, trans. Fornara 93, 139. Even if the temple was not actually built and the priestess not actually appointed until the 420 s, I could still accept a date soon after 440 for the first decree, as a part of the original plan for the Acropolis. For different recent views of the history of the building, see I. S. Mark, The Sanctuary of Athena Nike in Athens. Architectural Stages and Chronology (Hesp. Supp. 26 [1993]); I. M. Shear, 'The Western Approach to the Athenian Akropolis', $7 H S 119$ (1999), 120-5. For a recent study accepting an early date for the first decree on the basis of its lettering, see J. Lougovaya-Ast, 'Myrrhine: The First Priestess of Athena Nike', Phoen. 60 (2006), 211-25.

$33 I G \mathrm{i}^{3} 64$.

34 Ath. Pol. 8.1, 47.1. 
the opisthodomos with the treasurers of Athena. ${ }^{35}$ I mentioned above the decree of $c .460$ stating that the demos may use the funds of the Eleusinian goddesses, like the funds of Athena, as it wishes. ${ }^{36} \mathrm{My}$ guess is that, in the decrees of 434/433, the 3,000 talents which had been paid to Athena and the monies to be paid back to the Other Gods ${ }^{37}$ represented the repayment of sums borrowed from the sacred treasuries at the time of the Samian war in 440-439; certainly, from $433 / 432$ to the end of the Peloponnesian War, the state borrowed money from the sacred treasuries. ${ }^{38}$ It was presumably by state decision that the two treasuries were combined in 406/405, were separated again in $385 / 384$, and the treasury of the Other Gods was absorbed into that of Athena c.346. ${ }^{39}$

From 421/420, we have a decree regulating the festival of the Hephaestia, which is to be administered by one board of hieropoioi appointed from the men registered as jurors and another board appointed from the council. ${ }^{40}$ From 418/417, we have a decree concerning a sacred matter of another kind - the leasing of the temenos of Neleus, Basile and Codrus. The decree and an amendment prescribe the terms of the lease in detail: the lease is made by the basileus, the archon with particular religious responsbilities, in conjunction with the poletai, the state's regular contract-making officers; and the rent is to be paid to the apodektai, the state's regular revenue officers, who are to pass it on to the treasury of the Other Gods 'in accordance with the law'. ${ }^{41}$ In this connection we may note that, in the decree of the 450s for the Praxiergidae, mentioned above, the contract for the inscription is to be made by the poletai (as regularly) but payment for it is to be made from the treasury of Athena, 'in accordance with tradition', rather than from the state's secular

35 M\&L $58=I G \mathrm{i}^{3}$ 52, trans. Fornara 119.

$36 I G$ i $^{3} 6$; C. 32-8; cf. p. 2 above.

$37 \mathrm{M} \& \mathrm{~L} 58=I G \mathrm{i}^{3}$ 52, trans. Fornara 119, A. 2-13.

$38 \mathrm{M} \& \mathrm{~L} 72=I G \mathrm{i}^{3} 369$, part trans. Fornara 134, records sums borrowed and interest due in 426/425-423/422 with a summary for 433/432-427/426; I need not catalogue here the evidence for repayments and further borrowings after that.

39 For a foreshadowing of the amalgamation in 411, see Ath. Pol. 30.2; for 406/405, see W. S. Ferguson, The Treasurers of Athena (Cambridge, MA, 1932), 104-6, cf. more tentatively W. E. Thompson, 'Notes on the Treasurers of Athena', Hesp. 39 (1970), 61-3; for 385/384, see Ferguson, 14; for c.346, see Ferguson, 104-5, 118, A. M. Woodward, 'Two Attic Treasure-Records', HSCP Supp. 1 (1940), 404-6.

$40 I G \mathrm{i}^{3} 82$.

$41 I G \mathrm{i}^{3} 84$. The original decree seems to envisage the poletai as making the contract for fencing the temenos and the basileus as making the lease (lines 4-7), while the amendment makes the lessee do the fencing and, I believe more correctly, entrusts the leasing to the basileus and the poletai (lines 11-13) (Ath. Pol. 47. iv does not make it clear whether the poletai were involved with the basileus' leasing of sacred property). For the rent, see lines 14-18. 
treasury, by the treasurers of Athena and the kolakretai, the state's regular paying officers. ${ }^{42}$ It is not clear from the texts whether the apodektai and the kolakretai were regularly involved with receiving income for and making payments from the sacred treasuries, but it is clear that this sometimes happened.

For the undated decrees of the second half of the fifth century, $I G$ $\mathrm{i}^{3}$ has a separate category of decrees on religious matters: some are small fragments but others are reasonably substantial. These include decrees for a cult at Phalerum and for the cult of the Anaces, financed by contributions from sailors; ${ }^{43}$ and for contributions to a cult of Apollo to be collected from citizen soldiers by their demarchs and from archers by their officers, and administered by treasurers appointed by and from the council. ${ }^{44}$ There is also a decree on meals in the prytaneion for the closest descendants of Harmodius and Aristogiton, the killers of Hipparchus in 514, and for Athenian victors in the major Greek games, among others; ${ }^{45}$ and a decree about the cult of the Thracian goddess Bendis, mentioned at the beginning of Plato's Republic. ${ }^{46}$

Finally, for the fifth century, we must remember that the publication of a consolidated code of laws, begun in 410, resumed after the interval of the Thirty and completed in 399, included the publication of an updated calendar of festivals. Lysias' speech Against Nicomachus, one of the anagrapheis responsible for the work, complained that, in compiling the calendar, Nicomachus had omitted some traditional observances and inserted some new ones; and it appears that the anagrapheis were expecting trouble on this score since, in the version of the calendar inscribed after 403 (but not in the earlier version), they were careful to give the source for each item. Some of their rubrics seem to refer to categories within Solon's code, while $\dot{\epsilon}^{\prime} \kappa \hat{\omega} \nu$ $\sigma^{\dagger}[\eta \lambda \hat{\omega} \nu]$ ('from the stelai'), seems to refer to items added later. ${ }^{47}$

To sum up so far: from as early as the time of Solon, the state appointed the treasurers of Athena, just as it appointed secular officials, and its laws included a calendar of religious festivals. In the fifth

${ }^{42} I G \mathrm{i}^{3}$ 7. 6-9 (treasurers of Athena restored, kolakretai on the stone).

$43 I G \mathrm{i}^{3} 130$ (Delian Apollo restored tentatively by D. M. Lewis, but see A. P. Matthaiou, ' $E$ 's $I G \mathrm{i}^{3}$ 130', Hópos 14-16 [2000-3], 45-9), 133. Cf. the decree of the 450s for the cult of Poseidon at Sunium, $I G \mathrm{i}^{3} 8$ and above.

${ }^{44} I G \mathrm{i}^{3} 138$.

$45 I G \mathrm{i}^{3} 131$.

$46 I G$ i $^{3}$ 136; cf. Pl. Rep. 1. 327 A $1-5$.

47 Lys. 30. Nicomachus 17-21. For rubrics in the final version of the calendar, see S. Dow, 'The Law Codes of Athens', Proc. Mass. Hist. Soc. 71 (1953-7), 15-21; S. D. Lambert, 'The Sacrificial Calendar of Athens', BSA 97 (2002), 356-7. 
century, decrees of the state governed various cults and festivals; sacred treasurers, hieropoioi and other functionaries were state officials; the treasurers and their treasuries could be reorganized on the orders of the state; and the state claimed the right to draw on the funds accumulated in the sacred treasuries for its own purposes. Offerings to the gods, such as the offerings of first-fruits at Eleusis, were regulated by state decree; offerings at Eleusis and elsewhere from Athenian citizens were collected by demarchs; and the state decided that members of the Delian League should be required to send offerings, and that other Greeks should be invited to offer first-fruits at Eleusis, sending out heralds to announce this. In the second half of the fifth century, the state commissioned and supervised the erection of sacred buildings on the Acropolis, and wound up the Periclean programme as the Peloponnesian War approached. Long-established priesthoods continued to be restricted to particular families but, for Athena Nike, the state instituted a new priestess and prescribed that she was to be appointed from all Athenan women. The leasing of a temenos, which might have been left to the functionaries of the cult in question, was done under a decree of the state, though the basileus was involved with the poletai in the making of the lease; the rent, after being collected by the apodektai, was paid into the treasury of the Other Gods.

Moving on into the fourth century, I want not simply to pile up further instances of things we have already found, but to emphasize texts which add to the picture. I shall focus particularly on (roughly) the third quarter of the century, partly because that is a period in which there seems to have been exceptional activity in religious matters, partly because S. D. Lambert has been assigned 352/351$322 / 321$ for his share of the work on $I G \mathrm{ii}^{3}$ and, in one of his many preliminary studies, has provided a valuable survey of religious regulations from that period. ${ }^{48}$

Before that, briefly, some continuities: state control and, where appropriate, reorganization of sacred treasuries continued, as we have seen above with the history of the treasuries of Athena and of the Other Gods. We know from Demosthenes' speech against him that Androtion was appointed to work on the temple treasures, melting down old dedications and having new ones (more easily convertible to cash) made in their place, and that is to be linked with a decree dated

48 S. D. Lambert, 'Athenian State Laws and Decrees, 352/1-322/1, II. Religious Regulations', ZPE 154 (2005), 125-59 (henceforth Lambert). At p. 131 with notes 34-5 he lists religious regulations from 403 to 353 . 
365/364 by D. M. Lewis. ${ }^{49}$ Another decree, of 353/352, ordered a revised inventory of the objects in the chalkotheke. ${ }^{50}$ As in the fifth century, new cults were introduced from time to time: for instance, a cult of Eirene when the King's Peace was renewed in $375 / 374 .{ }^{51}$ In the 330s, there was a cult of Demokratia: the relief on the stele containing the anti-tyranny law of $337 / 336$ is interpreted as showing Demos crowned by Demokratia; the council set up a statue of her in $333 / 332$, and in the next two years the generals sacrificed to her. This was a time when what it meant to be democratic was disputed between Demosthenes and his opponents, and I think that that explains the particular emphasis in the 330s, but there was a painting of Demokratia and Demos set up in the stoa of Zeus about the middle of the century, Raubitschek accepted a suggestion that the cult had originally been instituted on the restoration of the democracy in 403, and recently $M$. H. Hansen has tried to trace the cult back into the late fifth century. ${ }^{52}$ The Eleusinian cult continues to be particularly well represented in inscriptions, with extensive regulations for the Mysteries inscribed c.367-348, ${ }^{53}$ a law about first-fruits inscribed some time before the middle of the century, ${ }^{54}$ another law about first-fruits dated $353 / 352,{ }^{55}$ and a decree of $349 / 348$ of which only the prescript survives. ${ }^{56}$

49 Dem. 22. Androtion 69-78; IG ii ${ }^{2} 216+261$, and a second copy 217, with D. M. Lewis, 'Notes on Attic Inscriptions, xiii. Androtion and the Temple Treasures', BSA 49 (1954), 39-49; cf. SEG xiv 47.

${ }^{50} I G \mathrm{ii}^{2} 120$, dated by E. Schweigert, 'Inscriptions from the North Slope of the Acropolis', Hesp. 7 (1938), 286-7.

51 Didym. Dem. 7.62-71 = Philoch. FGrH 328 F 151. For the cult statue, see Paus. 1.8.2, 9.16.2; a photograph of a Roman copy is in C. M. Robertson, A Shorter History of Greek Art (Cambridge, 1981), 138, pl. 190.

52 Anti-tyranny law Agora xvi $73=$ R\&O 79 with plate 7 ; for the statue, see $I G$ ii $^{2} 2791$ with A. E. Raubitschek, 'Demokratia', Hesp. 31 (1962), 238-43 = his The School of Hellas (New York, 1991), 223-8; for the generals' sacrifices, see $I G$ ii $^{2}$ 1496. 131-2, 140-1.

A suggested identification of the statue by O. Palagia, 'A Colossal Statue of a Personification from the Agora of Athens', Hesp. 51 (1982), 111-13, was withdrawn in idem, 'No Demokratia', in W. D. E. Coulson et al. (eds.), The Archaeology of Athens and Attica under the Democracy (Oxbow, 1994), 113-22. For disputes over democracy, see P. J. Rhodes, 'Democracy and its Opponents in Fourth-Century Athens', in U. Bultrighini (ed.), Democrazia e antidemocrazia nel mondo greco (Alessandria, 2006 but dated 2005), 282-5.

For the painting in the stoa of Zeus, apparently by Euphranor some time after the battle of Mantinea in 362, see Paus. 1.3.3-4. For the cult in 403, see Raubitschek (n. 52). For the cult in the late fifth century, see M. H. Hansen, 'Thucydides' Description of Democracy (2.37.1) and the EU-Convention', GRBS 48 (2008), 21-2.

53 Agora xvi 56 = Clinton, no. 138 (his dating).

54 Agora xvi 57.

$55 I G \mathrm{ii}^{2} 140=$ Clinton, no. 142 .

$56 I G$ ii $^{2} 209=$ Clinton, no. 78 . 
An interesting decree of $352 / 351$ adds to our range. ${ }^{57}$ Problems had arisen, as we know from the literary evidence, when the Athenians started cultivating part of the marginal land near Eleusis known as the sacred orgas, and the Megarians in response disputed the border between their territory and that of Athens. The decree provides (i) for the determination of the boundaries, by commissioners representing the council and the people, with the involvement of the basileus, the Eleusinian functionaries and any Athenian who wishes to participate; (ii) for consultation of the Delphic oracle as to whether part of the orgas should be leased out and the proceeds spent on works at Eleusis or the whole orgas should be left uncultivated; (iii) for the replacement of boundary stones. A very elaborate procedure is devised for the consultation of the oracle, so that the Pythia cannot know by human means which is which of the alternatives between which she has to choose: the two proposals are written on pieces of tin, which are rolled up and tied with wool, and then in a random way one is consigned to a gold jug and one to a silver; and the Pythia has to choose one of the jugs. The upshot, as we learn from a fragment of Philochorus, ${ }^{58}$ was that the whole orgas was to be left uncultivated.

Interest in sacred objects continued in Lambert's period with a decree concerning the repair of a statue of Athena Nike ${ }^{59}$ and two or more laws, the second proposed by Lycurgus, about cult equipment. ${ }^{60}$ A decree of 333/332, again proposed by Lycurgus, gives permission to a body of metics from Citium in Cyprus to acquire land for a sanctuary of Aphrodite, and cites as precedent a sanctuary of Isis established by men from Egypt. ${ }^{61}$

Lambert singles out as particularly frequent in the record of his period texts devoted to festival regulations. The best preserved is the top and bottom of a stele which began with a law and continued with a decree, enacted c. 335 and dealing with the Little Panathenaea. ${ }^{62}$ The law prescribes the leasing and taxing of land known as the Nea in order to fund the festival (the Nea is not certainly identified, but land acquired when Oropus was restored to Athens by Philip or Alexander is the best suggestion made so far); and (after a lacuna between the fragments) an amendment to the decree gives instructions for the performance of established sacrifices and of a sacrifice - possibly new

\footnotetext{
$57 I G \mathrm{ii}^{2} 204=\mathrm{R} \& \mathrm{O} 58=$ Clinton, no. 144.

58 Didym. Dem. 13.54-6 = Philoch. FGrH 328 F 155.

$59 I G \mathrm{ii}^{2} 403$ with Lambert, 135-6.

$60 I G$ ii $^{2} 333$ with Lambert, 137-43.

$61 I G \mathrm{ii}^{2} 337=\mathrm{R} \& \mathrm{O} 91$.

$62 I G$ ii $^{2} 334+S E G$ xviii $13=$ Agora xvi $75=\mathrm{R} \& \mathrm{O} 81$.
} 
or possibly established but with new funding - of cows bought from the rent of the Nea; and the surviving text ends with the all-night celebration and the dawn procession. Earlier, in 354/353, Epicrates had proposed a decree for the appointment of nomothetai to legislate on the financing of the Panathenaea. ${ }^{63}$

There is a decree of the council of 369/368, in a period when Athens possessed Oropus, for the repair of the sanctuary of Amphiaraus there; ${ }^{64}$ and Athens' recovery of Oropus in the 330s was followed by active interest in the sanctuary and cult of Amphiaraus, associated particularly with Phanodemus: from 332/331, we have a decree of his to crown Amphiaraus and a decree praising him for drafting laws for the festivals there; in 329/328, he served on the board which administered the festival (in a list of ten men, he is named first and Lycurgus second); and, in 328/327, he is named first of ten 'others' who joined twenty-one councillors in making a dedication at the Amphiaraum. ${ }^{65}$

There was a strong religious element in the ephebeia, revamped in the mid 330s as a training programme for all young Athenians or at least all those of hoplite class and above. The inscription which includes the text of the oath was probably set up in the 340 s, before the reform: that ends with an undertaking to 'honour the ancestral religion'; and Ath. Pol.'s account of the training programme begins with a tour of the sanctuaries. ${ }^{66}$

Lycurgus himself took an interest in all aspects of religion. Measures attributed to him in the Lives of the Ten Orators include honours for Neoptolemus for promising to gild the altar of Apollo in the agora; and laws on comic actors, statues and official texts of Aeschylus, Sophocles and Euripides, a festival of Poseidon at Piraeus, and women in the Eleusinian procession. ${ }^{67}$ Inscriptions refer to a

63 Decree $a p$. Dem. 24. Timocrates 27 (partly confirmed by the surrounding text).

64 I. Oropus 290.

${ }^{65}$ For his decree, see $I G$ vii $4252=F G r H 325 \mathrm{~T}$ 3. a; on praise for his laws, see $I G$ vii 4253 $=F G r H 325 \mathrm{~T} 3$. b; for the board of 329/328, see $I G$ vii $4254=F G r H 325 \mathrm{~T} 4$; for the dedication of 328/327, see Agora xv 49 with S. D. Lambert, 'Athenian State Laws and Decrees, 352/1-322/1, I. Decrees Honouring Athenians', ZPE 150 (2004), 99-101.

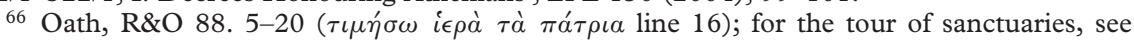
Ath. Pol. 42. iii.

67 On Neoptolemus, see [Plut.] X Or. 843 F, cf. Dem. 18. Crown 114; for his laws, see 841 F-842 A. For comic actors, see S. C. Humphreys, The Strangeness of Gods. Historical Perspectives on the Interpretation of Athenian Religion (Oxford, 2004), 253-4, suggesting that Phanodemus FGrH 325 FF 11-12 provided a historical justification. Poseidon at Piraeus was doubted by Parker (n. 9), 246 n. 100, but contrast J. D. Mikalson, Religion in Hellenistic Athens (Berkeley, CA, 1998), 23, 42. The story that Lycurgus' own wife broke the last law is a variation on a familiar theme and may well be invented, but need not discredit the attribution of the law to him. 
sacrifice and payments in connection with the Eleusinian cult, made in accordance with decrees of his. ${ }^{68}$

Another decree which Lycurgus proposed introduces us to a distinctive feature of this period: a new building programme, but (in contrast to that of the second half of the fifth century) one in which private individuals were encouraged to make their own contrubutions in return for suitable honours. Eudemus of Plataea was honoured in 329 because he

previously offered to the people to make a voluntary gift towards the war of 4,000 [?] drachmae if there were any need [I think this is a reference to the war against Macedon headed by Agis of Sparta in 331, and indicates that Lycurgus would have liked Athens to join in that war], and now has made a voluntary gift towards the making of the stadium and the Panathenaic theatre of a thousand yoke of oxen [where probably Panathenaic ought to have been attached to the stadium rather than the theatre]. ${ }^{69}$

Reminding us of one of our fifth-century inscriptions, Xenocles, an associate of Lycurgus, advanced money in 321/320 to build a bridge for the use of the Eleusinian procession. ${ }^{70}$

With that piece of ring composition, I will conclude. The inscriptions make it clear that every major aspect of religion in Athens was, or could be, controlled by the organs of the state. This does not mean either that Athens was a theocracy, in which power resided with individuals and bodies which were primarily religious, or that it was a society in which religion was weak and was subject to control by strong secular authorities. The Athenians did not distinguish between sacred and secular in that way, although the retention of separate sacred and secular treasuries, and the rule that sacred business was taken first in each meeting of the assembly, ${ }^{71}$ show that they did distinguish between sacred and secular in some ways. Rather, the organs of the state were organs of the citizens: religion was one of the concerns of the citizens, individually and collectively, and so the organs of the state were neither primarily religious nor distinctively secular, but involved themselves in religion just as they involved themselves in all the other matters that concerned the citizens. Religion was indeed 'embedded' in Athenian society and the Athenian state.

$68 I G \mathrm{ii}^{2} 1672.302$ (decree of council), 1672. 303, 1673. 65.

$69 I G \mathrm{ii}^{2} 351=$ R\&O. 94. 11-18.

$70 I G \mathrm{ii}^{2} 1191=$ Clinton, no. 95. 15-23. Cf. $I G \mathrm{i}^{3} 79=$ Clinton, no. 41 (422/421), above.

71 Ath. Pol. 43.6; cf. the access 'first after the sacred business' frequently granted from the beginning of the fourth century onwards, e.g. $I G \mathrm{ii}^{2} 24$. bc. 10-12. 